\title{
Allelopathic Potential of Sorghum Residues in Control of Two Weeds, the Great-Brome and Milk-Thistle

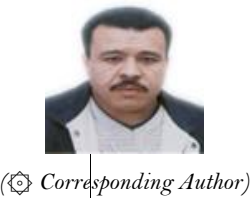

(Corresponding Author)

\author{
(D) Oussama OUESLATI ${ }^{1}$ \\ Gley ELHOULA ${ }^{2}$ \\ (iD) Moncef BEN-HAMMOUDA ${ }^{3}$
}

${ }^{1,2, s}$ Laboratory of Cereal Crop Physiology, Department of Agronomic Sciences and Rural Economy, Higher School of Agriculture of Kef, University of Jendouba, Tunisia. 'Email:oussamaoueslati@yahoo.fr Email: gleyelhoula@yahoo.fr

${ }^{s}$ Email: benhammoudamoncef@yahoo.com

\section{ABSTRACT}

Biological weed control through the use of the 'natural herbicide' potential of certain allelopathic crops could be an alternative to conventional herbicidal methods. This work was carried out to investigate the allelopathic potential of a 'Super Graze II' hybrid of forage sorghum (Sorghum bicolor L.), used as a cover crop by growers who practice conservation agriculture in Tunisia, to control two endemic weeds, the great-brome (Bromus diandrus) and milk-thistle (Silybum marianum), that infest the fields where winter straw cereals are grown in the semi-arid zone of Tunisia, causing yield losses. A bioassay was used to evaluate the phytotoxicity of sorghum plant components and root exudates. Water extracts of the sorghum expressed an inhibitory effect on the germination and seedlings' growth of the weeds. Radicle growth was more affected than coleoptiles growth. Stem-extract was the most phytotoxic on radicle growth of great-brome and milk-thistle with inhibition of $66 \%$ and $86 \%$, respectively. Regardless of the weed species, the effect of root exudates of sorghum was significant $(\mathrm{p}=0.05)$. Radicle length was more affected than coleoptiles length which was reduced by $42 \%$ and $71 \%$, for great-brome and milk-thistle, respectively. Sorghum was more efficient for milkthistle control. The results showed a potential use of sorghum as a natural herbicide, either alone or in combination with classical control methods. This practice should consider the choice of a cereal species/variety in succession tolerant to the phytotoxicity expressed by the sorghum hybrid.

Keywords: Allelopathy, Milk-thistle, Great-brome, Sorghum, Weed control.

DOI: $10.55284 /$ cjac.v7i1.602

Citation | Oussama OUESLATI; Gley ELHOULA; Moncef BEN-HAMMOUDA (2022). Allelopathic Potential of Sorghum Residues in

Control of Two Weeds, the Great-Brome and Milk-Thistle. Canadian Journal of Agriculture and Crops, 7(1): 11-19.

Copyright: This work is licensed under a Creative Commons Attribution 3.0 License

Funding: This study received no specific financial support.

Competing Interests: The authors declare that they have no competing interests.

History: Received: 15 December 2021 / Revised: 18 January 2022/ Accepted: 1 February 2022/ Published: 7 February 2022

Publisher: Online Science Publishing 


\section{Highlights of this paper}

- Allelopathic potential of Sorghum tissues and exudates were investigated.

- Allelopathy was identified based on bioassays techniques.

- Sorghum expressed allelopathic potential that reduced germination and growth of two weeds, great-brome (Bromus diandrus Roth.) and milk-thistle (Silybum marianum (L.) Gaertn).

- Potential use of sorghum residues, in case of practicing conservation agriculture, in weed control.

\section{INTRODUCTION}

During the first years of conservation agriculture practice, herbicides are applied more frequently than conventional tillage [1]. This excessive use of herbicides was reported to be behind the reduction of beneficial insects such as honey bees and lady beetles [2,3]. They contaminate surface water through runoff from treated fields. Ground water is also contaminated [4]. They have a deleterious effect on human health through accumulating in the food chain. Glyphosate causes inflammation, and affects lymphocyte functions and interaction between microorganisms and the immune system [5]. Also, the phenomenon of permanent or occasional herbicide resistance is a major concern for farmers who risk weed control failure because of the frequent use of some herbicides. The use of alternate herbicides to break weed habituation leaves little chance for economic yields, especially in the case of rain-fed cereals in the semi-arid zone of Tunisia.

Conservation agriculture offers a potential alternative to chemical weeding by incorporating cover crops with allelopathic properties to control weed development [6]. The bio-herbicide approach, based on the application of allelochemical compounds as a weed management tool, offers new opportunities to reduce the degree of the nuisance of many weed species while controlling the development of their resistance. This approach also avoids the ecological disorder caused by the excessive (unsustainable) use of synthetic chemicals, since allelochemicals have no residual or toxic effect [7]. Several crops were reported to have allelopathic effects against weeds. Residues of durum-wheat (Triticum durum Desf.) and rye (Secale cereale L.) release toxic substances that suppress weed populations such as common morning-glory (Ipomea purpurea L.) and prickly-sida (Sida spinosa L.) [8]. Barley (Hordeum vulgare L.) root exudates have inhibited the growth of ryegrass (Lolium rigidum L.) and great-brome [9]. Tissue extracts and root exudates of four sorghum grain (Sorghum bicolor L.) cultivars inhibited the growth of redroot-pigweed (Amaranthus retroflexus L.) [10]. Application of sorghum and brassica water extracts was behind reduction by $40 \%$ of dry biomass of two weeds, desert horse purstane (Trianthema portulacastrum L.) and purple nutsedge (Cyperus rotundus L.) [11]. Aqueous sorghum herbage extract was used to control weeds in wheat (Triticum aestivum L.), maize (Zea mays L.), and soybean (Glycine max L.) [12, 13]. Sorghum inhibition to weed growth is most probably due to the release of allelochemicals as cyanogenic glycoside (dhurrin) and phenolics [14, 15]. Considering the importance of weed control in conservation agriculture and producing in the spirit of sustainable development by reducing the use of herbicides as an input, the study was carried out to use sorghum allelopathy [16-18], for potential control of two straw cereal weeds, namely great-brome (Bromus diandrus Roth.) and milk-thistle [Silybum marianum (L.) Gaertn], in the semi-arid climate context.

\section{MATERIALS AND METHODS}

2.1. Field Experiments

A forage sorghum hybrid 'Super Graze II' was grown at the ESAK experimental station in the semi-arid zone of Tunisia during the 2006/07 growing season. The soil was alkaline $(\mathrm{pH}=8.3)$ with a low organic matter content of $1.8 \%$. It is a clayey-sandy-loamy soil ( $48 \%$ clay, $34 \%$ sand, $18 \%$ silt). 
Sorghum was conducted in eight plots of $24 \mathrm{~m}^{2}$ each, on fallow soil. The soil preparation consisted of one first deep plowing, followed by four offset crossings. Sorghum was sown by a precision drill with a rate of $30 \mathrm{~kg} / \mathrm{ha}$. The fertilization program was applied according to the vegetative stage of the plant. Fertilizer inputs were made by hand and fractionated. Phosphorus and potash were added during sowing and at the respective rates of 230 and 150 $\mathrm{kg} / \mathrm{ha}$. The ammonium nitrate was provided at $150 \mathrm{~kg} / \mathrm{ha}$ at early-tillering. In addition, no-tilled fallow soil was considered as a control. Irrigation was carried out using well water with a dry extract of $3.5 \mathrm{~g} / \mathrm{l}$. Irrigation management was carried out based on monitoring the soil's useful water reserve (UWR). Every time $60 \%$ of the UWR is exhausted, a contribution of $40 \mathrm{~mm}$ is provided. The total rainfall during the life cycle of sorghum was 51 $\mathrm{mm}$ of rainfall plus $880 \mathrm{~mm}$ of supplemental irrigation Table 1.

Table 1. Rainfall and irrigation complement, during the sorghum life cycle.

\begin{tabular}{|c|c|c|c|}
\hline Month & Rainfall (mm) & Number of irrigations & Rainfall + Irrigation (mm) \\
\hline June & 12.00 & 2 & 92.00 \\
\hline July & 2.00 & 6 & 242.00 \\
\hline August & 6.00 & 6 & 246.00 \\
\hline September & 5.00 & 4 & 165.00 \\
\hline October & 26.00 & 4 & 186.00 \\
\hline Total & 51.00 & 22 & 931.00 \\
\hline
\end{tabular}

\subsection{Weeds as a Test-Species}

The two weed test-species were: i) the great-brome, one of many annual winter species (Bromus rigidus L., Bromus rubens L., Bromus sterilis L.), which has spread widely, especially in durum-wheat fields, infesting 12,000 ha and reducing $80 \%$ of their yield [19], and ii) milk-thistle [20]. The grains of the two weeds were collected at the Kef valley during the 2006 growing season.

\subsection{Plant Material}

At maturity, stage 89 on the BBCH scale [21, 22], whole sorghum plants were randomly removed from each plot, washed, wiped, and dried in an oven for 24 hours at $50^{\circ} \mathrm{C}$. An estimate of the dry matter distribution of sorghum plant components (leaves, stems, roots) through the canopy of the whole plant was carried out. The dry matter distribution was 24, 56, and 20\%, respectively, for leaves, stems, and roots. Thus, these percentages of distribution are used to constitute the water-extracts of the whole plant (mixture). From the collected plants, the leaves, roots, and stems were separated, then washed in distilled water and placed between two paper towels, before being cut into $1 \mathrm{~cm}$ long pieces and stored in sterile containers at $5^{\circ} \mathrm{C}$ before extraction.

\subsection{Extraction of Plant Tissues}

A fraction of $5 \mathrm{~g}$ of each component (leaves, stems, roots) of the sorghum plant and the mixture of the three components was extracted in $100 \mathrm{ml}$ of distilled water. The mixture was made by respecting the relative proportion of each plant component through the sorghum canopy (unpublished data). The extraction was made in a $500 \mathrm{ml}$ Erlenmeyer and shaken horizontally at $200 \mathrm{rpm}$ for $24 \mathrm{~h}$. Then, the water extracts were filtered under vacuum through $0.2 \mathrm{~mm}$ pore filter paper, centrifuged at $12500 \mathrm{rpm}$ for $20 \mathrm{~min}$, and stored at $5^{\circ} \mathrm{C}$ until the bioassays [17].

\subsection{Soil-Extracts}

A $250 \mathrm{~g}$ sample of soil (in dry soil equivalent) cultivated with sorghum (soil-sorghum) was extracted in $250 \mathrm{ml}$ of distilled water, placed in a $500 \mathrm{ml}$ Erlenmeyer, and shaken at $200 \mathrm{rpm}$ for $24 \mathrm{~h}$. The water extracts were filtered 
under vacuum through a $0.2 \mathrm{~mm}$ pore filter before being centrifuged at $12500 \mathrm{rpm}$ for 20 min and stored at $5^{\circ} \mathrm{C}$ until the bioassay [23].

\subsection{Growth Medium Preparation}

A mixture of $1.2 \mathrm{~g}$ agar and $80 \mathrm{ml}$ distilled water was autoclaved at $120^{\circ} \mathrm{C}$ for $15 \mathrm{~min}$. After cooling below $50^{\circ} \mathrm{C}, 20 \mathrm{ml}$ of water extract from tissue (leaves, stems, roots, mixture) or soil cultivated with sorghum was added to the water-agar to give a medium of $1.2 \%$ water-agar-extract. The medium of $1.2 \%$ water-agar was used as a control.

\subsection{Effect of Sorghum Plant Components}

Extracts of sorghum plant components and of the whole plant were tested on germination and seedlings growth of two weeds (great-brome, milk-thistle) as test-species. For the germination bioassays, the seeds of the two weeds were sterilized with a $5 \%$ aqueous solution of sodium hypochlorite for 1 minute, then rinsed five times with distilled water, and finally dried between two paper towels. The surface sterilized seeds were placed in standard Petri dishes containing $15 \mathrm{ml}$ of water-agar, as a growth medium, amended with $20 \mathrm{ml}$ of extracts, and incubated for $36 \mathrm{~h}$ at $25^{\circ} \mathrm{C}$. Seeds with a $2 \mathrm{~mm}$ radicle length were considered germinated.

For seedlings' growth, the sterilized seeds of the two weeds were pre-germinated in Petri dishes between two paper towels impregnated with $2 \mathrm{ml}$ of distilled water each. Pre-germinated seeds were collected and placed in 10 test tubes each containing $15 \mathrm{ml}$ of water-agar-extracts at the rate of 1 seed per tube. The test tubes were covered with cotton and inclined at $45^{\circ}$ after the medium had flowed to allow it to solidify. After 60 hours of incubation at $25^{\circ} \mathrm{C}$, the lengths of the central radicle and the coleoptile were measured.

\subsection{Effect of Root Exudates}

To evaluate the effect of sorghum root exudates on the growth of the two weeds, sorghum was sown in 20-liter pots outdoor. Each pot received five seeds. The control pots were filled from the same soil but left unseeded to form a non-cultivated soil control. At the 3-leaf stage, 13 on the $\mathrm{BBCH}$ scale, the pots were thinned to one seedling/pot. A black plastic cover was used for each pot to prevent any leaching from the aerial parts of the plant from reaching the rhizosphere of the sorghum plant. The fertilization program, for the pots was similar, to the one used for the sorghum field trial. All pots were irrigated whenever a sign of wilting was observed. Irrigation started from the emergence and continued until the sorghum plant reached maturity (stage 89 on the BBCH scale for cereals).

At maturity, the whole sorghum plants were removed; the soil in the pots was dried in the open air for one day, then passed through a sieve of $0.3 \mathrm{~mm}$ stitches and stored at $5^{\circ} \mathrm{C}$ until extraction. For root exudates, in addition to negative control of distilled water-agar (1.2 $\mathrm{g}$ agar/ $100 \mathrm{ml}$ distilled water), a second positive control (soil-control) was considered. The soil was hand weeded. It was a mix of $1.2 \mathrm{~g}$ agar in $80 \mathrm{ml}$ of distilled water and $20 \mathrm{ml}$ of soil control-extracts.

\subsection{Data Analysis}

The germination and seedlings bioassays and pot test experiments were conducted in a Complete Randomized Design (CRD) with 4 repetitions. Data were subjected to analysis of variance using SAS package [24] with Fisher's protected test [25]. The $\mathrm{p}=0.05$ threshold LSD test was used to separate the means of any significant main effect [26]. 


\section{RESULTS}

\subsection{Effect of Sorghum Plant Components}

Extracts from plant components (leaves, stems, roots) and the mixture of sorghum manifested a highly significant effect on the germination of great-brome and milk-thistle Table 2 .

Table 2. Treatment mean squares for great brome and milk thistle germination, radicle, and coleoptile growth assayed with sorghum plant extracts.

\begin{tabular}{lccc}
\hline Test-species & Germination & Radicle length & Coleoptile length \\
\hline Great-brome & $606.82^{* *}$ & $3.54^{* * *}$ & $1.79^{* * *}$ \\
\hline Milk-thistle & $1278.92^{* * *}$ & $24.49^{* * *}$ & $1.89^{* * *}$ \\
\hline Note: ${ }^{* *}=$ significantly different at $\mathrm{p}=0.01,{ }^{* * * *}$ significantly different at $\mathrm{p}=0.001$. &
\end{tabular}

Stem-extracts were the most inhibitory, reducing germination by $37.8 \%$ and $47.8 \%$ for great-brome and milkthistle, respectively. Leaf-extracts were the least inhibitory (19.2\%) for great-brome germination, while the mixture-extracts were the least inhibitory (30.3\%) for milk-thistle germination Table 3.

Table 3. Effect of water extracts of sorghum plant on germination (\%), radical and coleoptiles length (cm) of great-brome and milk-thistle.

\begin{tabular}{|c|c|c|c|c|c|c|}
\hline \multirow[b]{2}{*}{ Treatment } & \multicolumn{2}{|c|}{ Germination } & \multicolumn{2}{|c|}{ Radicle length } & \multicolumn{2}{|c|}{ Coleoptile length } \\
\hline & $\begin{array}{l}\text { Great- } \\
\text { brome }\end{array}$ & $\begin{array}{l}\text { Milk- } \\
\text { thistle }\end{array}$ & $\begin{array}{l}\text { Great- } \\
\text { Brome }\end{array}$ & $\begin{array}{l}\text { Milk- } \\
\text { thistle }\end{array}$ & $\begin{array}{l}\text { Great- } \\
\text { Brome }\end{array}$ & $\begin{array}{l}\text { Milk- } \\
\text { thistle }\end{array}$ \\
\hline Control & $91.2^{a \dagger}$ & $95.7^{a \uparrow}$ & $3.8^{a \dagger}$ & $7.1^{\mathrm{a} \uparrow}$ & $3.0^{a+}$ & $3.2^{\mathrm{a} \downarrow}$ \\
\hline Mixture-extracts & $72.5^{\mathrm{b}}$ & $66.7^{b}$ & $2.2 \mathrm{bc}$ & $1.6^{b c}$ & $2.6^{\mathrm{b}}$ & $1.6^{\mathrm{c}}$ \\
\hline Stem-extracts & $56.7^{\mathrm{c}}$ & $50.0^{\mathrm{c}}$ & $1.3^{\mathrm{d}}$ & $1.0^{\mathrm{c}}$ & $1.3^{\mathrm{c}}$ & $1.6^{\mathrm{c}}$ \\
\hline Root-extracts & $70.0^{b}$ & $65.5^{\mathrm{b}}$ & $2.6^{\mathrm{b}}$ & $1.8 \mathrm{bc}$ & $2.8^{\mathrm{ab}}$ & $2.3^{b}$ \\
\hline Leaf-extracts & $73.7 \mathrm{~b}$ & $54.2^{\mathrm{c}}$ & $1.9^{\mathrm{cd}}$ & $2.4^{b}$ & $2.7^{\mathrm{ab}}$ & $2.7 \mathrm{~b}$ \\
\hline $\mathrm{LSD}(5 \%)$ & 14.5 & 11.1 & 0.6 & 1.1 & 0.4 & 0.5 \\
\hline
\end{tabular}

The effect of extracts from the different components and the mixture of the sorghum plant on the growth of the radicle of great-brome and milk-thistle was highly significant Table 2.

Again, stem-extracts were the most phytotoxic among the tested water-extracts for both weeds. They reduced great-brome radicle growth by $65.8 \%$, compared to control, while for milk-thistle the reduction was $85.9 \%$. Rootextracts were the least inhibitory (32\%) for great-brome radicle growth, and leaf-extracts were the least inhibitory $(66 \%)$ for milk-thistle Table 3. The effect of water extracts of sorghum plants on the growth of great-brome and milk-thistle coleoptile was highly significant Table 2.

As was the case for germination and radicle growth, stem-extracts were the most inhibitory, reducing coleoptile growth by $56.7 \%$ and $50 \%$ for great-brome and milk-thistle, respectively. The effect of sorghum mixtureextracts on coleoptiles growth of milk-thistle were similar to those of the stems. Root-extracts were the least inhibitory $(6.7 \%)$ for the growth of great-brome coleoptile and leaf-extracts were the least inhibitory (15.6\%) for milk-thistle growth of coleoptile Table 3.

Based on seedlings bioassays, the radicle growth of both weeds was more sensitive to water extracts than the growth of coleoptile, especially concerning stem-extracts of the sorghum plant. The latter were invariably the most phytotoxic. Based on the radicle bioassay, milk-thistle was by far the most sensitive to sorghum extracts Tables 3.

\subsection{Effect of Sorghum Root Exudates}

The effect of root exudates from soil cultivated with sorghum was significant on the germination of greatbrome and milk-thistle Table 4. 
Table 4. Treatment mean squares for great-brome and milk-thistle germination, radical and coleoptile growth assayed with sorghum root exudates.

\begin{tabular}{lccc}
\hline Test-species & Germination & Radicle length & Coleoptile length \\
\hline Great-brome & $1283.80^{* * *}$ & $3.02^{* * *}$ & $2.33^{* * *}$ \\
\hline Milk-thistle & $40.69^{* * * *}$ & $30.34^{* * * *}$ & $2.16^{* * * *}$ \\
\hline
\end{tabular}

Inhibition of great-brome and milk-thistle germination by exudates from soil-cultivated-sorghum in comparison distilled-water-control was $34.7 \%$ and $34.0 \%$, respectively. This inhibition, when compared to soilcontrol, was $32.9 \%$ and $37.8 \%$, respectively. There was a slight (-5.6\%), non-significant stimulation (-5.6\%) of milkthistle germination by the soil-control compared to the water-control, while great-brome germination was inhibited $(2.7 \%)$ in a non-significant way under the effect of the same extract Table 5.

Table 5. Effect of root exudates of sorghum plant on germination (\%), radical and coleoptiles length (cm) of great-brome and milk-thistle.

\begin{tabular}{|c|c|c|c|c|c|c|}
\hline \multirow[b]{2}{*}{ Treatment } & \multicolumn{2}{|c|}{ Germination } & \multicolumn{2}{|c|}{ Radicle length } & \multicolumn{2}{|c|}{ Coleoptile length } \\
\hline & $\begin{array}{l}\text { Great- } \\
\text { brome }\end{array}$ & $\begin{array}{l}\text { Milk- } \\
\text { thistle }\end{array}$ & $\begin{array}{l}\text { Great- } \\
\text { Brome }\end{array}$ & $\begin{array}{l}\text { Milk- } \\
\text { thistle }\end{array}$ & $\begin{array}{l}\text { Great- } \\
\text { Brome }\end{array}$ & $\begin{array}{l}\text { Milk- } \\
\text { thistle }\end{array}$ \\
\hline Soil-control & $91.2^{\mathrm{a} \uparrow}$ & $95.2^{\mathrm{a}+}$ & $3.8^{\mathrm{a}}$ & $7.0^{a+}$ & 3.2 a & $3.0^{\mathrm{a} \uparrow}$ \\
\hline Water-control & $93.7^{\text {a }}$ & $89.7^{\text {a }}$ & $3.5^{\mathrm{a}}$ & $6.6^{\mathrm{a}}$ & $3.1^{\mathrm{a}}$ & $3.2^{\mathrm{a}}$ \\
\hline Soil-cultivated-sorghum & $61.2^{\mathrm{b}}$ & $59.2^{\mathrm{b}}$ & $2.2^{\mathrm{b}}$ & $2.0^{\mathrm{b}}$ & $1.8^{b}$ & $1.7 \mathrm{~b}$ \\
\hline $\operatorname{LSD}(5 \%)$ & 6.6 & 10.2 & 0.6 & 1.0 & 0.4 & 0.3 \\
\hline
\end{tabular}

The effect of sorghum root exudates on the radicle length of both weeds was highly significant Table 4 .

Sorghum root exudates caused a reduction in great-brome and milk-thistle radicle growth of $42.1 \%$ and $71.4 \%$, respectively, compared to water-control. The reduction in radicle when compared to the soil-control was $37.1 \%$ and $69.7 \%$, respectively. Soil-control resulted in insignificant inhibition of radicle length of both weeds when compared to water-control Table 5 .

As was the case for germination and radicle growth of the two weeds, the effect of sorghum root exudates was highly significant on coleoptile growth Table 4.

Root exudates reduced the growth of coleoptile, compared to water-control by $43.8 \%$ and $43.3 \%$, respectively, for great-brome and milk-thistle. The same extract reduced the growth of coleoptile, compared to soil-control, by $41.9 \%$ and $46.9 \%$ for the two weeds, respectively. Again, soil-control was responsible a non-significant inhibition of great-brome coleoptile growth and for a non-significant antagonist effect by stimulation of milk-thistle Table 5 .

Again, radical growth inhibition of both weeds was more pronounced than that of germination and coleoptile growth. In addition, milk-thistle was once again much more sensitive than great-brome to sorghum root exudates.

\section{DISCUSSION}

Several authors have demonstrated that sorghum is an allelopathic species $[16,17,27]$. However, according to the available bibliography, no work has been carried out on the evolution of sorghum allelopathy in the climatic context of the Mediterranean semi-arid zone. Sorghum hybrids from the USA and other crops (alfalfa, barley) with allelopathic potentials were reported to be influenced by climatic conditions rather than heredity [17, 28, 29]. The results of the current study confirmed the presence of a significant allelopathic effect on the germination and growth of seedlings of two weeds (great-brome, milk-thistle) used as test species. The allelopathic potential of sorghum was perceptible as soon as the grain germinated, indicating the power of such potential. The radicle growth bioassay was found to be the most sensitive test for detecting sorghum allelopathy in the form of 
heterotoxicity. Radicle growth inhibition of both weeds was more pronounced than that of coleoptile. A similar result has been described by Ben-Hammouda, et al. [17]. Such a result indicates that the radicle growth bioassay alone is sufficient to detect and select the most allelopathic sorghum hybrids for the targeted weeds. The allelopathic potential of sorghum varied between the components of the sorghum plant. This differential effect has been reported for cereals as grain sorghum, durum-wheat, and barley [17, 30-32]. The phytotoxic effect of the sorghum plant was less pronounced on great-brome (Monocotyledonous plant, narrow leaf) than on milk-thistles (dicotyledonous plant, broad leaf), a similar result was reported by Einhellig and Rasmussen [27]. The stem was invariably the most phytotoxic component of the sorghum plant. This result is consistent with the works of Ben-Hammouda, et al. [17]; Yang, et al. [33] and Al-Khateeb, et al. [32].

In addition to the phytotoxicity/allelopathy of the sorghum plant tissues, the plant's roots synthesize and exude substances that can reduce the growth of the great-brome and milk-thistle. The response of the two weeds was differential. In previous studies, sorghum roots were recorded to have exuded allelochemicals, including sorgholeone, a bio-herbicide, that can inhibit or reduce the development of weed seedlings [16, 33, 34]. Roots of the same species were reported to have exuded phenolic acids (p-hydroxybenzoic, vanillic, syringe) which are allelochemicals [35]. Soil-control resulted in non-significant inhibition of germination and radicle length of both weeds. This inhibitory effect may be related to microbial activity in the soil [36].

Sorghum allelopathy has been identified at the laboratory level (bioassays, pots) as a predictive tool for the behavior for such potential in the field. This study clearly shows that the allelopathic potential of sorghum forage is well expressed in the semi-arid context and that it depends on the source of the water extract (leaves, stems, roots, mixture) and the targeted weed species. Finally, sorghum allelopathy can be considered as a potential means of biological weed management in straw cereal fields, especially in the case of conservation agriculture practices where residues are not disturbed at the field level. Sorghum allelopathy could be exploited by introducing the crop into rotations with winter crops or using its residues as mulch in the case of conservation agriculture. Allelopathy alone cannot replace conventional weed management practices; the use of herbicides would still be needed, but it would be reduced. In addition, the agronomic sequence in which sorghum residues are depressive for weeds and not for the economic species grown in succession should be selected. Field experiments must be carried out to detect the effect of sorghum's allelopathic potential on weed growth and the successively cultivated crop under real field conditions, thus allowing cereal growers to practice economically profitable agronomic sequences.

\section{REFERENCES}

[1] R. A. Jat, S. P. Wani, and K. L. Sahrawat, Conservation agriculture in the semi-arid tropics: Prospects and problems. India: In: Advances in Agronomy. Sparks D, L, 2012.

[2] L. Freydier and J. G. Lundgren, "Unintended effects of the herbicides 2, 4-D and dicamba on lady beetles," Ecotoxicology, vol. 25, pp. 1270-1277, 2016.Available at: https://doi.org/10.1007/s10646-016-1680-4.

[3] J. P. K. Gill, N. Sethi, A. Mohan, S. Datta, and M. Girdhar, "Glyphosate toxicity for animals," Environmental Chemistry Letters, vol. 16, pp. 401-426, 2018.Available at: https://doi.org/10.1007/s10311-017-0689-0.

[4] W. Aktar, D. Sengupta, and A. Chowdhury, "Impact of pesticides use in agriculture: Their benefits and hazards," Interdisciplinary Toxicology, vol. 2, pp. 1-12, 2009.Available at: https://doi.org/10.2478/v10102-009-0001-7.

[5] C. Peillex and M. Pelletier, "The impact and toxicity of glyphosate and glyphosate-based herbicides on health and immunity," Journal of Immunotoxicology, vol. 17, pp. 163-174, 2020.Available at: https://doi.org/10.1080/1547691x.2020.1804492. 
[6] N. Delabays, A. Ançay, and G. Mermillod, "Search for plant species with allelopathic properties," Swiss Journal of Viticulture, Arboriculture and Horticulture, vol. 30, pp. 383-387, 1998.

[7] P. Bhadoria, "Allelopathy: A natural way towards weed management," American Journal of Experimental Agriculture, vol. 1, pp. 7-20, 2011.Available at: https://doi.org/10.9734/ajea/2011/002.

[8] R. A. Liebl and A. D. Worsham, "Inhibition of pitted morning glory (Ipomoea lacunosa L.) and certain other weed species by phytotoxic components of wheat (Triticum aestivum L.) straw," Journal of Chemical Ecology, vol. 9, pp. 10271043, 1983.Available at: https://doi.org/10.1007/bfoo982209.

[9] I. Bouhaouel, A. Gfeller, M.-L. Fauconnier, S. Rezgui, H. S. Amara, and P. Du Jardin, "Allelopathic and autotoxicity effects of barley (Hordeum vulgare L. ssp. vulgare) root exudates," BioControl, vol. 60, pp. 425-436, 2015.Available at: https://doi.org/10.1007/s 10526-014-9634-3.

[10] I. Alsaadawi, M. Al-Ekelle, and M. Al-Hamzawi, "Differential allelopathic potential of grain sorghum genotypes to weeds," Allelopathy Journal, vol. 19, pp. 153-159, 2007.

[11] N. Iqbal, A. Khaliq, and Z. A. Cheema, "Weed control through allelopathic crop water extracts and S-metolachlor in cotton," Information Processing in Agriculture, vol. 7, pp. 165-172, 2020.Available at: https://doi.org/10.1016/j.inpa.2019.03.006.

[12] Z. A. Cheema, A. Khaliq, and H. M. I. Sadiq, "Efficacy of sorgaab (sorghum water extract) as a natural weed inhibitor in wheat," International Journal of Agriculture and Biology, vol. 2, pp. 144-146, 2000.Available at: http://doi.org/10.3923/pjbs.2000.1128.1130.

[13] Z. A. Cheema, A. Khaliq, and M. Farooq, Sorghum allelopathy for weed management in wheat. In Allelopathy in Sustainable Agriculture and Forestry. New York: Springer, 2008.

[14] Z. Cheema, M. Mushtaq, M. Farooq, and A. Hussain, "Purple nutsedge management with allelopathic sorghum," Allelopathy Journal, vol. 23, pp. 305-312, 2009.

[15] D. H. Netzly and L. G. Butler, "Roots of sorghum exude hydrophobic droplets containing biologically active components 1," Crop Science, vol. 26, pp. 775-778, 1986.

[16] F. Einhellig and I. Souza, "Allelopathic activity of sorgoleone," Journal of Chemical Ecology, vol. 18, pp. 1-11, 1992.

[17] M. Ben-Hammouda, R. J. Kremer, and H. C. Minor, "Phytotoxicity of extracts from sorghum plant components on wheat seedlings," Crop Science, vol. 35, pp. 1652-1656, 1995.Available at: https://doi.org/10.2135/cropsci1995.0011183x003500060023x.

[18] B. Urbano, F. Gonzalez-Andres, and A. Ballesteros, "Allelopathic potential of cover crops to control weeds in barley," Allelopathy Journal, vol. 17, pp. 53-64, 2006.

[19] T. Souissi, H. Belhadjsalah, M. Mhafdhi, and K. Latiri, "Non chemical control of Bromusdiandrus Roth. In wheat in Tunisia," in Proceedings of the 11th International Conference on Weed Biology, September 6-8. Dijon, France, 2000.

[20] C. Careme, "Les adventices des cultures méditerranéennes en Tunisie, leurs plantes, leurs semences," Publication Agricole, vol. 26, pp. 22-23, 1990.

[21] P. D. Lancashire, H. Bleiholder, T. v. d. Boom, P. Langelüddeke, R. Stauss, E. Weber, and A. Witzenberger, "A uniform decimal code for growth stages of crops and weeds," Annals of Applied Biology, vol. 119, pp. 561-601, 1991.

[22] A. Witzenberger, H. Hack, and T. Van Den Boom, "Explanations of the BBCH decimal code for the development stages of cereals," Gesunde Pflanzen, vol. 41, pp. 384-388, 1989.

[23] J. Read and E. Jensen, "Phytotoxicity of water-soluble substances from alfalfa and barley soil extracts on four crop species," Journal of Chemical Ecology, vol. 15, pp. 619-628, 1989.Available at: https://doi.org/10.1007/bfo1014705.

[24] SAS Institute, SAS user's guide: Statistics. Cary, NC, USA: SAS Institute Inc, 1985.

[25] R. G. D. Steel and J. H. Torrie, Principles and procedures of statistics. New York: McGraw- Hill, 1980. 
[26] T. M. Little and F. J. Hills, Agricultural experimentation: Design and analysis. New York: John Wiley and Sons, 1978.

[27] F. A. Einhellig and J. A. Rasmussen, "Effects of three phenolic acids on chlorophyll content and growth of soybean and grain sorghum seedlings," Journal of Chemical Ecology, vol. 5, pp. 815-824, 1979.Available at: https://doi.org/10.1007/bfoog86566.

[28] W. Guenzi, W. Kehr, and T. McCalla, "Water-soluble phytotoxic substances in Alfalfa Forage: Variation with variety, cutting, year, and stage of growth 1," Agronomy Journal, vol. 56, pp. 499-500, 1964.Available at: https://doi.org/10.2134/agronj 1964.00021962005600050016x.

[29] M. Ben-Hammouda, H. Ghorbal, R. Kremer, and O. Oueslati, "Allelopathic effects of barley extracts on germination and seedlings growth of bread and durum wheats," Agronomie, vol. 21, pp. 65-71, 2001.Available at: https://doi.org/10.1051/agro:2001109.

[30] O. Oueslati, M. Ben-Hammouda, M. Ghorbal, M. Guezzah, and R. Kremer, "Barley autotoxicity as influenced by varietal and seasonal variation," Journal of Agronomy and Crop Science, vol. 191, pp. 249-254, 2005.Available at: https://doi.org/10.1111/j.1439-037x.2005.00156.x.

[31] O. Oueslati, "Allelopathy in two durum wheat (Triticum durum L.) varieties," Agriculture, Ecosystems Eீ Environment, vol. 96, pp. 161-163, 2003.Available at: https://doi.org/10.1016/s0167-8809(02)00201-3.

[32] T. A. Al-Khateeb, I. Alsaadawi, and H. Hadwan, "Differentiation of allelopathic potential of sorghum (Sorghum bicolor) cultivars using chemical and molecular techniques," Tunisian Journal of Plant Protection, vol. 12, pp. 1-13, 2017.

[33] X. Yang, B. E. Scheffler, and L. A. Weston, "SOR1, a gene associated with bioherbicide production in sorghum root hairs," Journal of Experimental Botany, vol. 55, pp. 225 1-2259, 2004.Available at: https://doi.org/10.1093/jxb/erh252.

[34] M. A. Czarnota, R. N. Paul, F. E. Dayan, C. I. Nimbal, and L. A. Weston, "Mode of action, localization of production, chemical nature, and activity of sorgoleone: A potent PSII inhibitor in Sorghum spp. Root exudates," Weed Technology, vol. 15, pp. 813-825, 2001.Available at: https://doi.org/10.1614/0890-037x(2001)015[08 13:moalop]2.0.co;2.

[35] M. Ben-Hammouda, R. J. Kremer, H. C. Minor, and M. Sarwar, "A chemical basis for differential allelopathic potential of sorghum hybrids on wheat," Journal of Chemical Ecology, vol. 21, pp. 775-786, 1995.Available at: https://doi.org/10.1007/bfo2033460.

[36] S. Tongma, K. Kobayashi, and K. Usui, "Allelopathic activity of Mexican sunflower (Tithonia diversifolia) in soil," Weed Science, vol. 46, pp. 432-437, 1998.Available at: https://doi.org/10.1017/s0043 174500090858.

Online Science Publishing is not responsible or answerable for any loss, damage or liability, etc. caused in relation to/arising out of the use of the content. Any queries should be directed to the corresponding author of the article. 